\title{
Potable water source and the method of garbage disposal in lowering the risk of diarrhea
}

\author{
Putu Suriyasa ${ }^{*}$, Balgis $^{*}$, Ristu Saptono ${ }^{f}$, Mantrini Indri Hapsari*
}

\begin{abstract}
Abstrak
Masalah penyakit diare dapat dikendalikan melalui faktor lingkungan dan perilaku yang baik. Departemen Kesehatan telah membuat suatu indikator sederhana untuk menilai potensi kesehatan keluarga dengan Indeks Potensi Keluarga Sehat (IPKS). Studi ini bertujuan untuk menilai apakah IPKS dan indikator lain berpengaruh terhadap risiko diare. Data penelitian ini didapat dari hasil survei oleh tim peneliti Program Magister Kedokteran Keluarga Universitas Sebelas Maret pada bulan Agustus sampai September 2003 di antara keluarga miskin di lima propinsi yang memperoleh proyek Kesehatan Keluarga dan Gizi (KKG). Subjek terdiri dari 1500 kepala keluarga miskin yang dipilih dengan tahapan berjenjang dan secara acak. Pengisian kuesioner dan obervasi oleh tim peneliti secara langsung di rumah subjek. Keluarga yang menggunakan sumber air bersih dari ledeng dan sumur yang dibangun selama proyek KKG berlangsung berisiko $66 \%$ penyakit diare dibandingkan dengan yang menggunakan sumber air selain ledeng dan sumur (rasio odds suaian $=0,34 ; 95 \%$ interval kepercayaan $=0,16-0,70)$. Di samping itu, keluarga yang membuang sampah di lubang, selokan, sungai atau ditimbun mempunyai risiko diare sebanyak 2 kali lipat dibandingkan dengan keluarga yang mempunyai tempat sampah khusus. Untuk menurunkan risiko diare, diperlukan penyediaan sumber air sumur dan ledeng, dan bak tempat pembinaan sampah. Penggunaan kriteria rumah tidak terbuka dari tanah sebagai salah satu IPKS dalam pencegahan diare perlu penelitian lanjut. (Med J Indones 2004; 13: 119-26)
\end{abstract}

\begin{abstract}
The problem of diarrhea can be controlled through environmental factors and good habits. The Ministry of Health of the Republic of Indonesia has designed a simple indicator to evaluate the family health potential, the Family Health Potential Index (FHPI). This study aims to evaluate the effect of FHPI and other indicators on the risk of diarrhea. The data were obtained through a survey carried out by a team from the Family Physician Studies, Graduate Program of the Universitas Sebelas Maret. The survey was held from August to September 2003 in 5 provinces receiving the Family Health and Nutrition (FHN) project. The subjects were 1500 heads of poor families chosen by stratified random sampling. Interviews and observations were carried out by special trained interviewers and held in the subjects' homes. The use of potable water from the water system and well source built during the FHN project lowered the risk of diarrhea by 66\% compared to the use of water from other sources (adjusted odds ratio= 0.34; 95\% confidence interval $=0.16-0.70)$. Disposing of garbage using pits, sewers, rivers, or simply burying in the ground, increased the risk of diarrhea by twice compared with the specific method. Providing potable water from the water system or well and proving special tank for garbage disposal were important in order to lower the risk of occurrence diarrhea in a family. The use of non-dirt floors of houses as an FHPI specifically for diarrhea should be studied further. (Med J Indones 2004; 13: 119-26)
\end{abstract}

Keywords: diarrhea, potable water, garbage disposal, family health potential index, poor family

Diarrhea is still one of the major health problems in Indonesia. This is reflected by the high morbidity and mortality rates, especially in infants and under-fives. ${ }^{1}$ In the last five years, diarrhea has become the leading

\footnotetext{
*Family Medicine Studies, Graduate Program, Universitas Sebelas Maret, Surakarta, Indonesia

${ }^{f}$ Mathematics Studies, Faculty of Pedagogy and Educational Sciences, Universitas Sebelas Maret, Surakarta, Indonesia
}

cause of death in infants in developing countries. ${ }^{2}$ According to the World Health Organization (WHO), infectious diseases will still be the major health problem if environmental factors and habits are not improved. $^{3}$

It can be seen from various studies that the morbidity rate for diarrhea varies from year to year. Data from the Ministry of Health of the Republic Indonesia (MoH) Household Health Survey 1995 showed diarrhea to be the fifth ranking cause of death in 
Indonesia. ${ }^{3}$ In areas without facilities for providing adequate water and garbage treatments, the use of contaminated water is an major route of pathogens into the human body. ${ }^{4,5}$

Prevention of diarrhea through community efforts can be done by building human waste disposal facilities meeting health requirements, having a safe water supply, and controlling the vector (flies) population. On an individual and family basis, clean and healthy habits should be encouraged. ${ }^{6}$

In an effort to promote individual or family good habits in the community, the $\mathrm{MoH}$ through the Family Health and Nutrition (FHN) Project has devised the Family Health Potential Index (FHPI) as a basic for indicator of family health. The concept of FHPI refers to the Blum theory that health is the result of the environment, habits, and health services as well as inheritance. $^{\text {? }}$

The FHPI was designed as a tool for evaluating the degree of family and community health in a specific area. The index is quite simple and easy to determine, it can be used to predict the family and the community health status. The index evaluated the availability of potable water, latrines, types of floors of the houses, involvement in family planning for couples of childbearing age, monitoring growth and development of under-fives, none of the family member smokes, and is a member of some simple health insurance. If the family can fulfill all 7 indicators, then their FHPI is rated excellent. ${ }^{8}$ But whether the FHPI can be used to predict the risk of diarrhea in a family has yet to be proven. Therefore, the aim of this study is to determine how FHPI and other environmental variables can be used to determine the risk of diarrhea.

\section{METHODS}

This study is a cross-sectional survey. ${ }^{9,10}$ It is one of a series of studies carried out to evaluate the implementation of the FHN project in Indonesia dedicated for poor families. Data were collected from five provinces awarded the FHN project in 1997 until 2003. The names of the provinces are North Sumatera, Jambi, Bengkulu, Central Kalimantan, and South Kalimantan.

With stratification, 15 subdistricts were selected from 620 subdistricts in 15 districts of the 5 provinces. From each province, 3 subdistricts were selected from 3 different districts. The subjects were selected as a cluster of 100 heads of families for the sub district chosen. So there were 300 heads of families, or a total of 1500 heads of families from the 5 provinces. Primary and secondary data were collected on the independent variable, dependent variables and other supporting data. The sample family of FHN were directly interviewed by special trained for this study from August until September 2003.

Data were obtained through questionnaires and observation of the house and the surroundings by the investigators and trained local health center personnel. Interviews of the heads of the families were held in their homes.

The data collected were demographic characteristics such as age of the husband and wife, highest level of education of the husband and wife, occupation of the husband and wife, number of family members, illnesses in the last month. The FHPI associated to the risk of diarrhea were the type of flooring, the source of potable water, the latrines, monitoring growth and development of children, and environmental factors such as the type of house, method of garbage disposal, the distance between the toilet and water source, and waste treatment. Data were collected on nutrition, the sources of information, intervention of FHN including joining the group income generation, focus group discussion (FGD), communication, information, and education (CIE), counseling, environmental health stimulant, and home visits by health center personnel.

The category for flooring of the houses was either dirt floor or non-dirt floor. The category for source of potable water was a water system and well source or other sources of water. Family latrine was either present or not present. Monitoring growth and development of children was evaluated as either regularly weighing or not weighing the under-fives.

The types of housing was either temporary, semipermanent, or permanent buildings. The distance between latrines and potable water source was either less than 10 meters or more than 10 meters. ${ }^{11}$ The method of disposing garbage was divided into 3 categories, anywhere, thrown into a garbage bin, or others (such as in a pit, sewer, river or buried in the ground). The disposing of wastes was also divided into 3 groups, thrown into the sewers, thrown anywhere, and other ways.

The criteria for nutritional status were based the inclusion of the 4 food groups plus. Nutritional status 
was inadequate if not all of the 4 food groups were included and excellent if all the 4 groups are included plus milk. Access to information was evaluated as possessing a radio, television, video, and subscribing to a newspaper, magazine or by listening and reading health information from other sources or from health books.

Intervention by FHN included participating in FHN activities such as group income generating, FGD, CIE, environmental health stimulant, and visits by personnel of the health center. ${ }^{8}$

Diarrhea was only acknowledged if occurred one month prior to data collection in families participating in the FHN. Therefore, whatever the number of families members with diarrhea, it will only be counted as one event when it occurred in one family.

To determine the influence of the FHN project on the risk of diarrhea, facilities were identified whether they were present before FHN or during FHN. The FHN project was implemented in 1997-2002.

Data were analyzed using Stata 6.0. ${ }^{12}$ Univariate analysis was carried out to determine whether variables were risk factors or confounders to diarrhea. Factors with $\mathrm{p}$ value of $<0.25$ were considered as candidate, either as a risk factor or confounder, in the final multivariate model. ${ }^{13}$ In addition to the $p$ value, the odds ratio was also a deciding reason in including the variable to the final model. Risk factors and confounders were estimated using 95\% confidence interval based on the standard error of coefficient estimates.

\section{RESULTS}

Table 1 indicates that one thousand five hundred families participated in this study. The prevalence rate of diarrhea occurred one month prior to data collection in families was 5.7\%. Furthermore, it shows that the head of family who had educational level was senior high school or college or a family with the wife was self-employed more likely to experience diarrhea in his/her family during the last month to data collection compared with families who had never had formal education.

Table 2 shows that the biggest proportion of the type of housing of the subjects were temporary and semi permanent. It means the sample came from low income or poor families. The families with permanent or semi permanent built before the FHN project were less likely to experience diarrhea in his/her family during the last month to data collection.

Other potential confounders were the water source, if potable water was taken from the water system or well source, as was the availability of latrines, the method of garbage disposal, whether in a pit, sewer, river, or buried in the ground, along with the wastes thrown indiscriminately or by other means.

Compared with North Sumatera province, the other four provinces were less likely to experience diarrhea among the sample families. In addition, The family who had radio, or subscribing to a magazine, or subscribing before the FHN project, health information to books on health were less likely to experience diarrhea among their families compared with who did not do or have it (Table 3).

Table 4 shows that those who ever or still participating in group income generating, FGD, CIE, and environmental health stimulants (FHN programs) were less likely to experience diarrhea in his/her family during the last month to data collection compared with those who never participated on those FHN programs.

In the final model (Table 5) shows that potable water from the water system and well source built during the FHN project was found to lower the risk of diarrhea by $66 \%$ compared to potable water from nonwater system or well water. In term of the method of garbage disposal (which is not a FHN project activity), it was found that families disposing their garbage in no specific places, pits, sewers, river, or buried in the ground was noted two-folds to increase risk of getting diarrhea. 
Table 1. Demographic characteristics of subject (age, education, employment) and the risk of diarrhea

\begin{tabular}{|c|c|c|c|c|c|c|c|}
\hline & \multicolumn{2}{|c|}{$\begin{array}{l}\text { No diarrhea } \\
(\mathrm{N}=1415)\end{array}$} & \multicolumn{2}{|c|}{$\begin{array}{l}\text { Diarrhea } \\
(\mathrm{N}=85)\end{array}$} & \multirow[t]{2}{*}{$\begin{array}{l}\text { Crude odds } \\
\text { ratio }\end{array}$} & \multirow{2}{*}{$\begin{array}{c}95 \% \\
\text { confidence } \\
\text { intervals } \\
\end{array}$} & \multirow[t]{2}{*}{$\mathrm{p}$} \\
\hline & $n$ & $\%$ & $\mathrm{n}$ & $\%$ & & & \\
\hline \multicolumn{8}{|l|}{ Age of husband } \\
\hline $19-30$ years & 188 & 13.3 & 15 & 17.7 & 1.00 & Reference & \\
\hline $30-80$ years & 1227 & 86.7 & 70 & 82.3 & 0.72 & $0.40-1.26$ & 0.256 \\
\hline \multicolumn{8}{|l|}{ Age of wife } \\
\hline $15-30$ years & 438 & 31.4 & 27 & 31.8 & 1.00 & Reference & \\
\hline $30-75$ years & 958 & 68.6 & 58 & 68.2 & 0.98 & $0.61-1.57$ & 0.940 \\
\hline \multicolumn{8}{|l|}{ Education of husband } \\
\hline None & 117 & 8.3 & 4 & 4.7 & 1.00 & Reference & \\
\hline Elementary school & 836 & 59.1 & 2 & 1.2 & 1.82 & $0.65-5.12$ & 0.257 \\
\hline Junior high school & 237 & 16.7 & 14 & 16.5 & 1.73 & $0.56-5.37$ & 0.344 \\
\hline Senior high school & 189 & 13.4 & 13 & 15.3 & 2.01 & $0.64-6.32$ & 0.231 \\
\hline College & 11 & 0.8 & 2 & 2.4 & 5.32 & $0.87-32.38$ & 0.070 \\
\hline University & 2 & 0.1 & 0 & 0.0 & $\mathrm{n} / \mathrm{a}$ & - & - \\
\hline Others & 23 & 1.6 & 0 & 0.0 & $\mathrm{n} / \mathrm{a}$ & - & - \\
\hline \multicolumn{8}{|l|}{ Education of wife } \\
\hline None & 121 & 8.7 & 7 & 8.2 & 1.00 & Reference & \\
\hline Elementary school & 880 & 63.0 & 52 & 1.2 & 1.02 & $0.45-2.30$ & 0.959 \\
\hline Junior high school & 241 & 17.3 & 14 & 16.5 & 1.01 & $0.40-2.55$ & 0.993 \\
\hline Senior high school & 126 & 9.0 & 11 & 12.9 & 1.51 & $0.57-4.02$ & 0.410 \\
\hline College & 2 & 0.1 & 0 & 0.0 & $\mathrm{n} / \mathrm{a}$ & - & \\
\hline Others & 26 & 1.9 & 1 & 1.2 & 0.66 & $0.08-5.64$ & 0.708 \\
\hline \multicolumn{8}{|l|}{ Occupation of husband } \\
\hline Unemployed & 34 & 2.4 & 2 & 2.4 & 1.00 & Reference & \\
\hline Household & 22 & 1.6 & 1 & 1.2 & 0.77 & $0.07-9.04$ & 0.837 \\
\hline Laborer & 14 & 0.9 & 10 & 11.8 & 1.21 & $0.25-5.80$ & 0.808 \\
\hline Farmer & 851 & 60.1 & 49 & 57.7 & 0.98 & $0.23-4.19$ & 0.977 \\
\hline Self-employed & 67 & 4.7 & 4 & 4.7 & 1.02 & $0.18-5.82$ & 0.987 \\
\hline Office worker & 9 & 0.6 & 0 & 0.0 & $\mathrm{n} / \mathrm{a}$ & - & - \\
\hline Armed Forces/Police & 13 & 0.9 & 0 & 0.0 & $\mathrm{n} / \mathrm{a}$ & - & - \\
\hline Craftsman & 260 & 18.4 & 19 & 22.4 & 1.24 & $0.28-5.57$ & 0.777 \\
\hline Others & 19 & 1.3 & 0 & 0.0 & $\mathrm{n} / \mathrm{a}$ & - & - \\
\hline \multicolumn{8}{|l|}{ Occupation of wife } \\
\hline Unemployed & 94 & 6.7 & 4 & 4.7 & 1.00 & Reference & \\
\hline Household & 493 & 35.3 & 30 & 35.3 & 1.43 & $0.49-4.15$ & 0.511 \\
\hline Laborer & 48 & 3.4 & 4 & 4.7 & 1.96 & $0.47-8.17$ & 0.357 \\
\hline Farmer & 703 & 50.4 & 42 & 49.4 & 1.40 & $0.49-4.00$ & 0.684 \\
\hline Self-employed & 35 & 2.5 & 5 & 5.9 & 3.36 & $0.85-13.22$ & 0.083 \\
\hline Office worker & 5 & 0.4 & 0 & 0.0 & $\mathrm{n} / \mathrm{a}$ & - & - \\
\hline Armed Forces/Police & 1 & 0.1 & 0 & 0.0 & $\mathrm{n} / \mathrm{a}$ & - & - \\
\hline Craftsman & 6 & 1.2 & 0 & 0.0 & $\mathrm{n} / \mathrm{a}$ & - & - \\
\hline Others & 1 & 0.1 & 0 & 0.0 & $\mathrm{n} / \mathrm{a}$ & & \\
\hline
\end{tabular}

Note: $\mathrm{n} / \mathrm{a}=$ not applicable 
Table 2. Environmental factors, infant weight and the risk of diarrhea

\begin{tabular}{|c|c|c|c|c|c|c|c|}
\hline & \multicolumn{2}{|c|}{$\begin{array}{l}\text { No diarrhea } \\
(\mathrm{N}=1415)\end{array}$} & \multicolumn{2}{|c|}{$\begin{array}{l}\text { Diarrhea } \\
(\mathrm{N}=85)\end{array}$} & \multirow[t]{2}{*}{$\begin{array}{c}\text { Crude } \\
\text { odds ratio }\end{array}$} & \multirow{2}{*}{$\begin{array}{c}95 \% \\
\text { confidence } \\
\text { intervals }\end{array}$} & \multirow[t]{2}{*}{$\mathrm{p}$} \\
\hline & $\mathrm{n}$ & $\%$ & $\mathrm{n}$ & $\%$ & & & \\
\hline \multicolumn{8}{|l|}{ Type of housing } \\
\hline Temporary & 156 & 11.0 & 11 & 12.9 & 1.00 & Reference & \\
\hline Semi permanent & 1017 & 71.9 & 66 & 77.7 & 0.92 & $0.48-1.78$ & 0.805 \\
\hline Permanent & 76 & 5.4 & 3 & 3.5 & 0.56 & $0.15-2.07$ & 0.384 \\
\hline Permanent-pre-FHN & 166 & 11.7 & 5 & 5.9 & 0.43 & $0.15-1.26$ & 0.122 \\
\hline \multicolumn{8}{|l|}{ Floor type } \\
\hline Dirt & 61 & 4.3 & 4 & 4.7 & 1.00 & Reference & \\
\hline Non-dirt & 283 & 20.0 & 23 & 27.1 & 1.24 & $0.41-3.71$ & 0.701 \\
\hline Non-dirt pre-FHN & 1071 & 75.7 & 58 & 68.2 & 0.83 & $0.29-2.35$ & 0.720 \\
\hline \multicolumn{8}{|l|}{ Latrines } \\
\hline None & 489 & 34.6 & 34 & 40 & 1.00 & Reference & \\
\hline Toilet & 554 & 39.2 & 27 & 31.8 & 0.70 & $0.42-1.18$ & 0.180 \\
\hline Toilet pre-FHN & 372 & 26.3 & 24 & 28.2 & 0.93 & $0.54-1.59$ & 0.786 \\
\hline \multicolumn{8}{|l|}{ Distance of latrines to water source } \\
\hline Less than $10 \mathrm{~m}$ & 613 & 43.3 & 34 & 40.0 & 1.00 & Reference & \\
\hline More than $10 \mathrm{~m}$ & 298 & 21.1 & 14 & 16.5 & 0.85 & $0.45-1.60$ & 0.610 \\
\hline More than $10 \mathrm{~m}$ pre-FHN & 504 & 35.6 & 37 & 45.5 & 1.32 & $0.82-2.14$ & 0.253 \\
\hline \multicolumn{8}{|l|}{ Source of potable water } \\
\hline Non water system or well water & 405 & 28.6 & 35 & 41.2 & 1.00 & Reference & \\
\hline Water system-well water during FHN & 362 & 25.6 & 11 & 12.9 & 0.35 & $0.18-0.71$ & 0.003 \\
\hline Water system-well water pre-FHN & 648 & 45.8 & 39 & 45.9 & 0.70 & $0.44-1.12$ & 0.134 \\
\hline \multicolumn{8}{|l|}{ Garbage disposal } \\
\hline Specific place & 876 & 61.9 & 44 & 51.8 & 1.00 & Reference & \\
\hline No specific place & 274 & 19.4 & 19 & 22.4 & 1.38 & $0.79-2.41$ & 0.255 \\
\hline Others & 265 & 18.7 & 22 & 25.9 & 1.65 & $0.97-2.81$ & 0.063 \\
\hline \multicolumn{8}{|l|}{ Household wastes } \\
\hline No specific place & 404 & 28.6 & 17 & 20.0 & 1.00 & Reference & \\
\hline Into the sewers & 732 & 51.7 & 48 & 56.5 & 1.56 & $0.88-2.75$ & 0.125 \\
\hline Others & 279 & 19.7 & 20 & 23.5 & 1.70 & $0.88-3.31$ & 0.116 \\
\hline \multicolumn{8}{|l|}{ Weighing of infants } \\
\hline Yes & 446 & 89.1 & 36 & 85.7 & 1.00 & Reference & \\
\hline No & 55 & 10.9 & 6 & 14.3 & 1.35 & $0.55-3.35$ & 0.516 \\
\hline
\end{tabular}


Table 3. Source of information (radio, television, information on health, magazines, books on health, newspapers), nutritional state, name of province and the risk of diarrhea

\begin{tabular}{|c|c|c|c|c|c|c|c|}
\hline & \multicolumn{2}{|c|}{$\begin{array}{l}\text { No diarrhea } \\
(\mathrm{N}=1415)\end{array}$} & \multicolumn{2}{|c|}{$\begin{array}{c}\text { Diarrhea } \\
(\mathrm{N}=85)\end{array}$} & \multirow[t]{2}{*}{$\begin{array}{l}\text { Crude Odds } \\
\text { Ratio }\end{array}$} & \multirow{2}{*}{$\begin{array}{c}95 \% \\
\text { confidence } \\
\text { intervals }\end{array}$} & \multirow[t]{2}{*}{$\mathrm{p}$} \\
\hline & $\mathrm{n}$ & $\%$ & $\mathrm{n}$ & $\%$ & & & \\
\hline \multicolumn{8}{|l|}{ Radio } \\
\hline None & 572 & 40.4 & 26 & 30.6 & 1.00 & Reference & \\
\hline Possess & 322 & 22.8 & 18 & 21.2 & 1.23 & $0.66-2.28$ & 0.511 \\
\hline Possess pre-FHN & 521 & 36.8 & 40 & 48.2 & 1.73 & $1.04-2.87$ & 0.033 \\
\hline \multicolumn{8}{|l|}{ TV } \\
\hline None & 793 & 56.0 & 44 & 51.8 & 1.00 & Reference & \\
\hline Possess & 249 & 17.6 & 16 & 18.8 & 1.16 & $0.64-2.09$ & 0.626 \\
\hline Possess pre-FHN & 373 & 26.4 & 25 & 29.4 & 1.21 & $0.73-2.00$ & 0.464 \\
\hline \multicolumn{8}{|l|}{ Information on health } \\
\hline None & 456 & 32.2 & 26 & 30.6 & 1.00 & Reference & \\
\hline Receive & 523 & 37.0 & 41 & 48.2 & 1.38 & $0.83-2.28$ & 0.219 \\
\hline Receive pre-FHN & 436 & 30.8 & 18 & 21.2 & 0.72 & $0.39-1.34$ & 0.304 \\
\hline \multicolumn{8}{|l|}{ Magazines } \\
\hline None & 1323 & 93.5 & 71 & 83.5 & 1.00 & Reference & \\
\hline Subscribe & 49 & 3.5 & 9 & 10.6 & 3.42 & $1.62-7.24$ & 0.001 \\
\hline Subscribe pre-FHN & 43 & 3.0 & 5 & 5.9 & 2.17 & $0.83-5.64$ & 0.113 \\
\hline \multicolumn{8}{|l|}{ Books on health } \\
\hline None & 1064 & 75.2 & 60 & 70.6 & 1.00 & Reference & \\
\hline Subscribe & 195 & 13.8 & 17 & 20.0 & 1.55 & $0.88-2.71$ & 0.127 \\
\hline Subscribe pre-FHN & 156 & 11.0 & 6 & 9.4 & 0.91 & $0.43-1.94$ & 0.806 \\
\hline \multicolumn{8}{|l|}{ Newspaper } \\
\hline None & 1333 & 94.2 & 81 & 95.3 & 1.00 & Reference & \\
\hline Subscribe & 40 & 2.8 & 4 & 4.7 & 1.65 & $0.58-4.71$ & 0.353 \\
\hline Subscribe pre-FHN & 42 & 3.0 & 0 & 0.0 & & & \\
\hline \multicolumn{8}{|l|}{ Nutritional state } \\
\hline Low & 1281 & 90.53 & 77 & 90.6 & 1.00 & Reference & \\
\hline Adequate & 75 & 5.30 & 6 & 7.1 & 1.33 & $0.56-3.15$ & 0.516 \\
\hline Good & 59 & 4.17 & 2 & 2.4 & 0.56 & $0.14-2.35$ & 0.432 \\
\hline \multicolumn{8}{|l|}{ Name of province } \\
\hline Sumatera Utara & 271 & 19.15 & 29 & 34.1 & 1.00 & Reference & \\
\hline Jambi & 284 & 20.07 & 16 & 18.8 & 0.53 & $0.28-0.99$ & 0.047 \\
\hline Bengkulu & 297 & 20.99 & 3 & 3.5 & 0.09 & $0.02-0.31$ & 0.000 \\
\hline Kalimantan Tengah & 281 & 19.86 & 19 & 22.4 & 0.63 & $0.35-1.15$ & 0.135 \\
\hline Kalimantan Selatan & 282 & 19.93 & 18 & 21.2 & 0.60 & $0.32-1.10$ & 0.098 \\
\hline
\end{tabular}


Table 4. Family health and nutrition interventions and the risk of diarrhea

\begin{tabular}{|c|c|c|c|c|c|c|c|}
\hline & \multicolumn{2}{|c|}{$\begin{array}{c}\text { No Diarrhea } \\
(\mathrm{N}=1415)\end{array}$} & \multicolumn{2}{|c|}{$\begin{array}{l}\text { Diarrhea } \\
(\mathrm{N}=85)\end{array}$} & \multirow[t]{2}{*}{$\begin{array}{c}\text { Crude } \\
\text { odds ratio }\end{array}$} & \multirow{2}{*}{$\begin{array}{c}95 \% \\
\text { confidence } \\
\text { intervals }\end{array}$} & \multirow[t]{2}{*}{$\mathrm{p}$} \\
\hline & $\mathrm{n}$ & $\%$ & $\mathrm{n}$ & $\%$ & & & \\
\hline \multicolumn{8}{|c|}{ Group income generation } \\
\hline Never & 123 & 8.7 & 11 & 12.9 & 1.00 & Reference & \\
\hline Sometime & 592 & 41.8 & 28 & 32.9 & 0.53 & $0.26-1.09$ & 0.085 \\
\hline Regularly & 700 & 49.5 & 46 & 54.1 & 0.74 & $0.37-1.46$ & 0.378 \\
\hline \multicolumn{8}{|c|}{ Focus group discussion } \\
\hline Never & 62 & 4.4 & 7 & 8.2 & 1.00 & Reference & \\
\hline Sometime & 661 & 46.7 & 28 & 32.9 & 0.38 & $0.16-0.89$ & 0.027 \\
\hline Regularly & 692 & 48.9 & 50 & 58.8 & 0.64 & $0.28-1.47$ & 0.293 \\
\hline \multicolumn{8}{|l|}{ CIE* } \\
\hline Never & 192 & 13.6 & 17 & 20.0 & 1.00 & Reference & \\
\hline Sometime & 748 & 52.9 & 26 & 30.6 & 0.39 & $0.21-0.74$ & 0.004 \\
\hline Regularly & 475 & 33.6 & 42 & 49.4 & 0.10 & $0.56-1.80$ & 0.996 \\
\hline \multicolumn{8}{|l|}{ Counseling } \\
\hline Never & 105 & 7.4 & 7 & 8.2 & 1.00 & Reference & \\
\hline Sometime & 767 & 54.2 & 36 & 42.4 & 0.70 & $0.31-1.62$ & 0.410 \\
\hline Regularly & 543 & 38.4 & 42 & 49.4 & 1.16 & $0.51-2.65$ & 0.725 \\
\hline \multicolumn{8}{|l|}{ Home visit } \\
\hline Never & 85 & 6.0 & 4 & 4.7 & 1.00 & Reference & \\
\hline Sometime & 687 & 48.6 & 44 & 51.8 & 1.36 & $0.48-3.88$ & 0.564 \\
\hline Regularly & 643 & 45.4 & 37 & 43.5 & 1.22 & $0.43-3.52$ & 0.709 \\
\hline \multicolumn{8}{|c|}{$\begin{array}{l}\text { Environmental health } \\
\text { stimulant }\end{array}$} \\
\hline Never & 597 & 42.2 & 47 & 5.3 & 1.00 & Reference & \\
\hline Sometime & 490 & 34.6 & 19 & 22.4 & 0.49 & $0.29-0.85$ & 0.011 \\
\hline Regularly & 328 & 23.2 & 19 & 22.4 & 0.74 & $0.41-1.27$ & 0.274 \\
\hline
\end{tabular}

*Communication, Information, Education (CIE)

Table 5. Interaction between health education, source of potable water, garbage disposal and the risk of diarrhea

\begin{tabular}{|c|c|c|c|c|c|c|c|}
\hline & \multicolumn{2}{|c|}{$\begin{array}{c}\text { No diarrhea } \\
(\mathrm{N}=1415)\end{array}$} & \multicolumn{2}{|c|}{$\begin{array}{c}\text { Diarrhea } \\
(\mathrm{N}=85)\end{array}$} & \multirow[t]{2}{*}{$\begin{array}{c}\text { Adjusted } \\
\text { odds ratio* }\end{array}$} & \multirow{2}{*}{$\begin{array}{c}95 \% \\
\text { confidence } \\
\text { intervals }\end{array}$} & \multirow[t]{2}{*}{$\mathrm{p}$} \\
\hline & $\mathrm{n}$ & $\%$ & $\mathrm{n}$ & $\%$ & & & \\
\hline \multicolumn{8}{|l|}{ Source of potable water } \\
\hline Non- water system or well water & 405 & 28.6 & 35 & 41.2 & 1.00 & Reference & \\
\hline Water system-well water during FHN project & 362 & 25.6 & 11 & 12.9 & 0.34 & $0.16-0.70$ & 0.003 \\
\hline Water system-well water pre-FHN & 648 & 45.8 & 39 & 45.9 & 0.65 & $0.40-1.08$ & 0.094 \\
\hline \multicolumn{8}{|l|}{ Garbage disposal } \\
\hline Specific place & 876 & 61.9 & 44 & 51.8 & 1.00 & Reference & \\
\hline No specific place & 274 & 19.4 & 19 & 22.4 & 1.62 & $0.90-2.93$ & 0.110 \\
\hline Others & 265 & 18.7 & 22 & 25.9 & 1.97 & $1.11-3.50$ & 0.021 \\
\hline
\end{tabular}

\footnotetext{
* Adjusted each other for variables listed on this table, information on health, and communication, information, and education on health
} 


\section{DISCUSSION}

Several constraints in this study may influence interpretation the data. There were no supporting data that can be used to verify the validity of the data collected, such as the timing of family water and latrine availability. In addition, the study covered a vast area, with natural boundaries such as a river and even a sea between one area and another area, compounded by the unfamiliarity of the investigators to the area designated. To overcome these constraints, interviews were held in-depth to elaborate on the answers given. The investigators have also trained the local health center personnel thoroughly before the study. They also act as guide for the investigators.

In calculating the relative risk for the final model, the source of potable water, either from the water system and well source, yet present before FHN was included. This will demonstrate the difference in the quality of water produced by the water system or well source built before FHN and by FHN.

The result obtained in the final model showed that potable water from the water system and well built by FHN lowered the risk of diarrhea when compared with water from sources. This result is supported earlier studies. ${ }^{1,14}$ Even though geographically different, studies held in other developing countries have also revealed that the infrastructure for water treatment were repaired in stages. ${ }^{4}$

The method for garbage disposal, such as using a pit, sewer, river, or burying, was found to influence the risk of diarrhea. This may be due to incomplete treatment of garbage. This finding was also supported by earlier studies. ${ }^{4,14}$

This study reveals the risk of diarrhea was related to the availability of potable water to the family. Where as the availability of latrines, and non-dirt floors of houses, were not found to be associated with diarrhea. From the FHPI parameters, in term of preventing diarrhea, non-dirt floors of houses were not significantly or related to prevent diarrhea.

\section{CONCLUSIONS}

In order to lower the risk of diarrhea, special attention should be given to potable water from sources other than the water system or well, and to the method of disposing garbage in pits, sewer, river or buried in the ground. The use of non-dirt floors of houses as indicators of family health potential index specifically for diarrhea should be studied further.

\section{Acknowledgements}

The authors wish to thank all the subjects, the local health office and health center personnel in the five provinces receiving FHN that have participated in this study. Special thanks are given to the Department of Health through the ADB Project Loan that has supported this study. And lastly to Drs. Bastaman Basuki and Minarma Siagian for providing technical assistance and reviewing the earlier drafts of this manuscript that improved the final product.

\section{REFERENCES}

1. Irianto J, Soesanto SS, Inswiasri S, Irianti S, Anwar A. Factors influencing diarrhea in children and under-fives [Indonesian]. Bull Indones Health Research 1996;24:7795.

2. Bern C, Martines J, de Zoysa I, Glas RI. The magnitude of the global problem of diarrhoeal disease: A ten year update. Bull World Health Org 1992;70:705-14.

3. Ministry of Health of the Republic of Indonesia. Diarrhea and its prevention [Indonesian]. Jakarta: The Ministry; 1993.

4. Quick RE, Kimura A, Thevos A, Tembo M, Shamputa I, Hutwagner L, et al. Diarrhea prevention through household-level water disinfection and safe storage in Zambia. Am J Tropical Med Hyg 2002;66:584-9.

5. Tauxe RV, Mintz ED, Quick RE. Epidemic cholera in the new world: translating field epidemiology into new prevention strategies. Emerg Infect Dis 1995;1:141-6.

6. Zuraida. Healthy living habits: guide for health workers [Indonesian]. Jakarta: Ministry of Health Rep of Indones; 2000.

7. Blum HL. Planning for health, development, and application of social change theory. New York: Human Science; 1974.

8. Trihono. Progress report on family health and nutrition project [Indonesian]. Jakarta: Ministry of Health Rep of Indones; 2001.

9. Murti B. Principles of research methodology [Indonesian]. Vol 2. 2nd ed. Yogyakarta: Gadjah Mada University Press; 2003.

10. Rossi PH, Primen EH. Evaluation: systematic approach. 4th ed. California: Sage Publication Inc.; 1989.

11. Requirements and control of water quality, Publ L of Indonesia No. 416 (1990).

12. Stata Corp. Stata statistical software: Release 6.0. Texas: University Drive College Station; 1999.

13. Hosmer DW, Lemeshow S. Applied logistic regression. 2nd ed. New York: John Willey \& Sons; 2000.

14. Wijono, Sunaryo, Lapau B. Epidemiologic surveillance on diarrheal cases in Soppeng district, South Sulawesi [Indonesian]. Epidemiol News. 1993. 
